\title{
Motivation for different physical activities: a comparison among sports, exercises and body/movement practices ${ }^{1}$
}

\author{
Rafael Ming Chi Santos Hsu* (1) \\ Jaroslava Varella Valentova
}

\author{
Universidade de São Paulo, Instituto de Psicologia, Department of Experimental Psychology, São Paulo, Brazil
}

\begin{abstract}
Despite the well-known benefits for health, low levels of physical activity (PA) remain a public health issue. Research on motives for engaging in different PA shows differences in motives for Sports and Exercises. However, few studies addressed motives using more categories of PA. In this research, we investigated motives for four categories of PA (Individual Sports, Collective Sports, Exercises, and Body/Movement Practices), and possible effects of sex and age among 1,420 physically active individuals. Respondents answered the Motivation for Physical Activity Measure Revised. Intrinsic motives were higher for Sports, while Exercisers were motivated more extrinsically. Body/Movement Practices, although being composed of several activities defined by previous studies as Exercises, showed a motivational pattern closer to Sports. Fitness/Health motivation increased with age, while Appearance motivation decreased. Regarding sex, women reported higher Interest/ Enjoyment than men. Our results can have implications for physical activities promotion, especially considering more categories than Sports/Exercises in the context of different motives.
\end{abstract}

Keywords: motivations, sport, exercise, body/movement practice.

\section{Introduction}

Research on motivation for physical activities (PA) commonly addresses the contrast between evidence for mental and physical benefits, and it shows that a substantial portion of the population does not meet the standards of PA guidelines (Aaltonen, Kujala, \& Kaprio, 2014; Andrade Bastos, Salguero, \& Gonzáles-Boto, 2006; Ryan, Frederick, Lepes, Rubio, \& Sheldon, 1997). Studies on motivation for PA can shed some light on this paradox.

PA can be defined as a voluntary movement with energy costs superior to rest levels, aimed to attain some goal linked to Kinesiology dimensions (e.g., self-expression, leisure, health and/or competition) (Caspersen, Powell, \& Christenson, 1985; Hoffman \& Harris, 2013). PA can be classified into specific domains, such as leisure, household, transportation and occupational (see, e.g., Florindo et al., 2009).

Among leisure time PA, a common classification splits PA into Sports and Exercises. Sport is a specific PA related to the use of skilled movement in game contexts, including competition, rules, and search for records (Hoffman \& Harris, 2013). Sports can be divided into Individual (e.g., tennis, karate, gymnastics) and Collective/ Team (e.g., football, rugby, basketball, volleyball) (Gillet \& Rosnet, 2008). Exercise (e.g., bodybuilding, jogging, walking, stretching, functional training), in turn, is considered a structured PA, repetitive movements

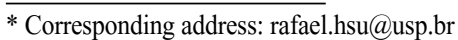

aimed at enhancing physical fitness or conditioning (Caspersen et al., 1985).

Previous studies showed greater intrinsic motivation - refers to doing an activity for itself and the pleasure (Ryan \& Deci, 2000) - for Sports and greater extrinsic motivation (directed at attaining or avoiding something outside the self) for Exercises (Frederick \& Ryan, 1993; Kilpatrick, Hebert, \& Bartholomew, 2005; Ryan et al., 1997). Some studies showed that intrinsic motivation can be more frequent for specific PA. For example, collective sportists are motivated in particular by social reasons (Kilpatrick et al., 2005). Other studies showed differences in motivation for PA between men and women. Particularly, women are systematically more motivated than men by appearance (Apostolou \& Lambrianou, 2017; Frederick \& Ryan, 1993; Molanorouzi, Khoo, \& Morris, 2015; Murcia, Gimeno, \& Camacho, 2007; Ryan et al., 1997), while men are more motivated by the social aspect of PA (Andrade Bastos et al., 2006; Apostolou \& Lambrianou, 2017; Kilpatrick et al., 2005). Motivation can also change with age. Appearance-based PA motivation is stronger among younger individuals, while Fitness/Health motivation increases with age (Andrade Bastos et al., 2006; Apostolou \& Lambrianou, 2017; Murcia et al., 2007). Moreover, younger individuals report relatively higher Social, Competence, and Interest/Enjoyment motivation for PA

1 We would like to thank the Research Grant \#2016/22964-0 and Research Grant \#2018/13937-4, São Paulo Research Foundation (Fapesp). 
(Andrade Bastos et al., 2006; Apostolou \& Lambrianou, 2017; Molanorouzi et al., 2015).

Since most previous studies have not compared more than two categories of PA, Frederick and Ryan (1993) suggested the importance of using a more detailed classification, because it could potentially clarify the dynamics of relationships between motivation and PA. Since then, however, we believe only a few attempts have been made toward more detailed classifications, such as Team Sport, Individual Racing plus Bowls, Racquet, Exercises, and Martial Arts (Molanorouzi et al., 2015). Other studies analyzed motivation for specific PA, showing for example higher intrinsic motivation for Taekwondo practitioners in comparison to Aerobics (Ryan et al., 1997). We believe no Brazilian study has yet analyzed motivations for more detailed categories of PA.

Furthermore, some previous classifications yielded criticism. For example, classifying Yoga in terms of modern PA dimensions has been criticized because of its occidentalization (Gnerre, 2010). Because Yoga includes many additional principles (e.g., spirituality, philosophy, historical traditions), practitioners and teachers do not accept Yoga to be categorized as an Exercise and even less as a Sport (Nunes, 2008). Similarly, the categorization of dance as an exercise has also been criticized, and, in general, dancers do not fit themselves into Physical Education $^{2}$. Thus, there are still many PA that appear to not fit either into sports or exercises.

\section{Aims and Hypotheses of the current study}

The aim of this study was to compare motivations of men and women among several different PA. We also tested possible effects of sex and age on motivations for the studied PA.

Based on previous literature (Frederick \& Ryan, 1993; Kilpatrick et al., 2005; Ryan et al., 1997), we expected different motivations between practitioners of Sports and Exercises. In particular, Sport participants were expected to have more intrinsic motivations (Competence and Interest/Enjoyment) than exercisers, while Exercisers were expected to show more Appearance and Fitness/Health motivations than Sport participants. Social motivations were also expected to be higher in Sport practitioners. We predicted that a separate category of PA, which do not meet the definition of both sports and exercises, would show a unique pattern of motivations. We followed previous literature that coined the term "Body/Movement Practice" to describe PA in ways that can be different from Sports and Exercises (Lazzarotti Filho, Silva, Antunes, Silva, \& Leite, 2010), and we hypothesized that Body/Movement Practices would adopt an intermediary position in the motivations between Sports and Exercises.

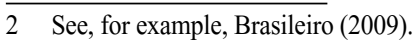

We expected higher Appearance and Fitness/ Health motivations in women and more sociability in men.

Finally, we expected to find higher scores of Interest/Enjoyment and Appearance motivations in younger participants, and Fitness/Health motivations in older participants.

\section{Methods}

\section{Participants}

Participants were recruited by convenience, through mailing lists to students, professors and other employees of a Brazilian university and also by polling the general public through social networks (Facebook and WhatsApp). The only requirement was to be 18 or older. Out of the 2,652 respondents $($ mean age $=25.86, \mathrm{SD}=9.81)$, we analyzed 1,420 who considered themselves physically active (mean age $=26.83, \mathrm{SD}=10.49), 564$ men $($ mean age $=28.05$, $\mathrm{SD}=11.40$ ) and 856 women (mean age $=25.98$, $\mathrm{SD}=9.70$ ). A t-test has shown a significant age difference between men and women, with men being significantly older than women $(\mathrm{t}(2)=4.804, \mathrm{p}<0.001)$.

\section{Instruments}

This study is part of a broader project aimed at relations between personality and motivations for PA. The research consisted of several standardized questionnaires, and here we report instruments relevant only for this study.

The participants completed a basic sociodemographic questionnaire and indicated the physical activity they most practiced. Based on this information, activities were classified by the first author as: Individual Sport, Collective Sport or Exercise. An additional category - Body/Movement Practice - was created, to group, by exclusion of PA that do not meet clearly the definitions of Sports (eminently competitive) or Exercises (emphasizing physical conditioning), such as Yoga, Pilates, Tai Chi Chuan, Liang Gong, dances, and Gymnastics for All.

As shown in Table 1, a larger proportion of participants declared Exercise as the primary leisure-time PA. Table 2 shows all activities considered for the research and their respective categorization into the four categories.

The participants filled in the Motivation for Physical Activity Measure Revised (Ryan et al., 1997) that measures, in 30 items answered on 7-point likert scales, five motivational factors related to PA: intrinsic (Interest/ Enjoyment, Competence) and extrinsic (Fitness/Health, Appearance, Social) motivation. The internal consistency measured by Cronbachs' alphas were: Interest/Enjoyment $(\alpha=.92)$; Competence $(\alpha=.90)$; Appearance $(\alpha=.89)$; Fitness/Health $(\alpha=.80)$ and Social $(\alpha=.85)$. 
Table 1. Distribution of types of physical activities

\begin{tabular}{|c|c|c|c|c|c|c|}
\hline & Total N & $\%$ & $\operatorname{Men} N$ & $\%$ & Women $N$ & $\%$ \\
\hline Individual Sport & 281 & 19.6 & 141 & 25.0 & 137 & 16.0 \\
\hline Collective Sport & 243 & 17.0 & 107 & 19.0 & 134 & 15.7 \\
\hline Exercise & 721 & 52.9 & 291 & 51.7 & 423 & 49.5 \\
\hline Body/Movement Practice & 186 & 10.6 & 24 & 4.3 & 160 & 18.7 \\
\hline Total (sample) & 1,431 & 100.0 & 563 & 100.0 & 854 & 100.0 \\
\hline
\end{tabular}

Table 2. All physical activities indicated by the participants and their respective categorization (Exercise, Individual Sport, Collective Sport, Body/Movement Practices)

\begin{tabular}{|c|c|c|c|}
\hline Category & \multicolumn{3}{|c|}{ Physical Activities } \\
\hline $\begin{array}{l}\text { Exercise } \\
(\mathrm{n}=721)\end{array}$ & $\begin{array}{l}\text { Exercises at gym - } 334 \\
\text { (Strength - 297, Crossfit - 17; Aerobics - 13; } \\
\text { Spinning - 5, Jumping; Localized) } \\
\text { Running - } 147 \\
\text { Walking - } 89 \\
\text { (general - 88, simulator - 1) } \\
\text { Exercises (other) - 59 (not specified - 51; At home - 4; } \\
\text { Without weights - 2; For column, Physical conditioning) }\end{array}$ & $\begin{array}{l}\text { Bycicling/Bike }-21 \\
\text { Functional training }-16 \\
\text { Gymnastics }-11 \\
\text { Hydrogymnastics }-8 \\
\text { Calisthenics }-3 \\
\text { Body pump }-2 \\
\text { Fitness - } 2 \\
\text { Jump rope - } 2 \\
\text { Body jump } \\
\text { Deep running }\end{array}$ & $\begin{array}{l}\text { Dogs (activities with) } \\
\text { Hiit } \\
\text { Horse riding } \\
\text { Labor gymnastics } \\
\text { Morphofunctional } \\
\text { training (Menegatti) } \\
\text { Stretching } \\
\text { Tae Bo } \\
\text { Trekking } \\
\text { Virtual gym } \\
\end{array}$ \\
\hline $\begin{array}{l}\text { Individual Sport } \\
\qquad(\mathrm{n}=281)\end{array}$ & $\begin{array}{l}\text { Martial Arts }-96 \\
\text { (Kung fu }-18 \text {, Karate }-15 \text {, Muay Thay }-14 \text {, Boxing }-9 \text {, } \\
\text { Jiu-jitsu }-8 \text {, Judo }-8 \text {, not specified }-7 \text {, Taekwondo }-5 \text {, } \\
\text { Capoeira }-4 \text {, Krav magá }-3 \text {, Kendo }-2 \text {, Fencing, Hapkido), } \\
\text { Swimming }-68 \\
\text { (not specified - 67; high performance }-1 \text { ), } \\
\text { Racquet }-40 \\
\text { (Tennis }-28 \text {, Table tennis }-9 \text {, Badminton }-3 \text { ) }\end{array}$ & $\begin{array}{l}\text { Cycling }-27 \\
\text { Athletics }-26 \\
\text { Pole dance }-12 \\
\text { Road running }-7 \\
\text { Weightlifting }-4 \\
\text { Climbing }-2 \\
\text { Roller }-2 \\
\text { Surf }-2\end{array}$ & $\begin{array}{l}\text { Acrobatic gymnastics } \\
\text { Archery } \\
\text { Breaking dance } \\
\text { Kettlebell lifting } \\
\text { Pole sport } \\
\text { Skate } \\
\text { Triathlon }\end{array}$ \\
\hline $\begin{array}{l}\text { Collective Sport } \\
\qquad(\mathrm{n}=243)\end{array}$ & $\begin{array}{l}\text { Foot }-84 \\
(\text { Futsal }-47, \text { Soccer }-37) \\
\text { Volleyball }-43 \\
\text { Handball }-33 \\
\text { Basketball }-32 \\
\end{array}$ & $\begin{array}{l}\text { Rugby }-19 \\
\text { Boat }-11 \\
\text { (Rowing }-9 \text {, Canoeing }-2 \text { ) } \\
\text { Baseball }-5 \\
\text { American football }-4\end{array}$ & $\begin{array}{l}\text { Cheerleading }-3 \\
\text { Softballl }-3 \\
\text { Water polo }-2 \\
\text { Ultimate frisbee }\end{array}$ \\
\hline $\begin{array}{c}\text { Body/Movement } \\
\text { Practices } \\
(\mathrm{n}=186)\end{array}$ & $\begin{array}{l}\text { Dance }-81 \\
\text { (General }-32 \text {, Ballet }-24 \text {, Belly dance }-5 \text {, Zumba }-5 \text {, } \\
\text { Jazz }-4 \text {, Tai Ko }-4 \text {, Ballroom dance }-2 \text {, Tap dance }-2 \text {, } \\
\text { Contemporary dance, German folk dance, Urban dance) } \\
\text { Pilates }-54 \\
\text { Yoga }-26\end{array}$ & $\begin{array}{l}\text { Circus }-4 \\
\text { Parkour }-3 \\
\text { Aikido }-2 \\
\text { Tai Chi Chuan } \\
\text { Taisou }\end{array}$ & $\begin{array}{l}\text { Aerial silk } \\
\text { Ashtanga } \\
\text { Equitation } \\
\text { Holistic Gymnastics } \\
\text { Pi-Yo }\end{array}$ \\
\hline
\end{tabular}

Note: Physical Activities without number were mentioned only once as the most practiced PA.

\section{Procedure}

Data were collected online using Qualtrics software (Qualtrics, Provo, UT). All participants read the consent form and confirmed their anonymous participation in the study, taking, on average, $25 \mathrm{~min}$. No reward was provided for participating in the study. The project was approved by the IRB of Institute of Psychology, University of São Paulo (number 1.506.899, approved on April 19th, 2016).

\section{Statistical Analyses}

Analyses were conducted with Statistical Package for Social Sciences (SPSS) version 21.0. To test for effect of type of PA, sex and age on motivations, we performed Multivariate General Linear Models (GLM) with type of motivation as dependent variable, while type of PA (Individual Sport, Collective Sport, Body/Movement Practice, Exercise) 
and sex entered as fixed factors. Age entered as a covariate. Test of Between-Subject Effects estimated the main effects and Estimated Marginal Means with Bonferroni correction were consulted as post-hoc tests. All effect sizes are reported in partial eta square $\left(\eta_{p}^{2}\right)$.

\section{Results}

\section{Effect of type of physical activity, sex and age on motivation for physical activity}

GLM showed significant effects of type of PA - Individual Sport, Collective Sport, Exercise and Body/Movement Practice [Wilks' Lambda $=.637$, $\mathrm{F}(3,4)=45.384, \mathrm{p}<.001$.], age [Wilks' Lambda $=.944$, $\mathrm{F}=16.47, \mathrm{p}<.001$ ], and sex [Wilks' Lambda $=.993$, $\mathrm{F}(1,2)=2.440, \mathrm{p}=.033]$.

As shown in Table 3, Interest/Enjoyment motivation was the highest for Collective Sports than all the other types of PA (all p's < .033), while Exercises scored the lowest on this motivational dimension (all p's $<.001$ ). Individual Sports and Body/Movement Practices did not differ from each other $(\mathrm{p}=.510)$.

In the Competence dimension, Individual and Collective Sports did not differ from each other $(\mathrm{p}=1.00)$, and Body/Movement Practice also did not differ from either Individual $(\mathrm{p}=.378)$ or Collective Sport $(\mathrm{p}=.261)$. Both Sports and Body/Movement Practice scored higher than Exercises (all p's < .049).

Appearance-based PA motivation in Exercises was the one that differed the most from the three other types of PA (all p's < .001). It was further higher in Individual Sport than Collective Sport $(\mathrm{p}=.003)$, and
Body/Movement Practice did not differ either from Individual Sport $(p=.288)$ or Collective Sport $(p=1.000)$.

Fitness/Health was the second most important motivation for Exercise that differed from the three other types of PA (all p's < .001). Fitness/Health motivation was higher in Individual Sport than Collective Sport $(\mathrm{p}<.001)$, and Body/Movement Practice did not differ either from Individual Sport $(p=.105)$ or Collective Sport $(\mathrm{p}=1.000)$.

Social motives were the strongest for Collective Sports that differed from the three other types of PA (all p's < .001). In sequence, Individual Sports scored higher than Exercises $(\mathrm{p}<.001)$, but not Body/Movement Practices $(\mathrm{p}=.572)$. Body/Movement Practices also scored higher than Exercises $(\mathrm{p}<.001)$.

Further, Sex was a significant predictor of the Interest/Enjoyment for physical activities with women showing higher Interest/Enjoyment than men (mean difference $=.217, \mathrm{SE}=.095, \mathrm{p}=.022$ ). There was no other effect of sex.

Moreover, there was a negative correlation between age and Appearance-based PA motivation $(\mathrm{r}=-.054$, $\mathrm{p}=0.042$ ), while a positive correlation was found for Fitness/Health $(\mathrm{r}=.125, \mathrm{p}<.001)$

Finally, considering the participants as a whole, the highest means reported for motivations were Fitness/ Health $(5.79, \mathrm{SD}=1.15)$, followed by Interest/Enjoyment (5.47, $\mathrm{SD}=1.40)$, Competence $(4.84, \mathrm{SD}=1.58)$, Appearance (4.73, $\mathrm{SD}=1.62)$ and Social $(2.79, \mathrm{SD}=1.56)$. A univariate ANOVA showed significant differences among all these motivation types (all p's $<.001$ ), except for Competence and Appearance, which did not differ from each other $(\mathrm{p}=.32)$.

Table 3. Differences between mean scores $( \pm S D)$ of motivational dimensions divided into four types of Physical Activities

\begin{tabular}{lccccc}
\hline & $\begin{array}{c}\text { Individual Sport- } \\
\text { Mean (SD) }\end{array}$ & $\begin{array}{c}\text { Collective Sport- } \\
\text { Mean (SD) }\end{array}$ & $\begin{array}{c}\text { Exercise- } \\
\text { Mean (SD) }\end{array}$ & $\begin{array}{c}\text { Body/Movement Practice- } \\
\text { Mean }(\text { SD) }\end{array}$ & F statistics \\
\hline Interest/Enjoyment & $5.90(.077)^{2}$ & $6.23(.085)^{1}$ & $4.94(.050)^{3}$ & $5.63(.142)^{2}$ & $67.29^{* *}$ \\
Competence & $5.29(.092)^{1}$ & $5.33(.101)^{1}$ & $4.46(.059)^{2}$ & $4.93(.168)^{1}$ & $28.00^{* * *}$ \\
Appearance & $4.36(.090)^{2}$ & $3.90(.098)^{3}$ & $5.32(.058)^{1}$ & $3.99(.164)^{2,3}$ & $63.67^{* *}$ \\
Fitness/Health & $5.73(.066)^{2}$ & $5.31(.072)^{3}$ & $6.05(.042)^{1}$ & $5.40(.121)^{2,3}$ & $25.85^{* *}$ \\
Social motivation & $3.15(.082)^{2}$ & $4.21(.090)^{1}$ & $2.21(.053)^{3}$ & $2.86(.151)^{2}$ & $122.59^{* *}$ \\
\hline
\end{tabular}

Means $\left( \pm S D\right.$ ) with the same uppercase letters do not differ from each other (using Bonferroni's post-hoc comparisons). ${ }^{* *} \mathrm{p}<.001$

\section{Differences in self-reported practice of PA among sexes and Relations between Age and Type of PA}

To analyze if sex was related to the practice or lack of PA, a Chi-Square test was made. We found significant sex difference in prevalence of practice $\left(x^{2}(1,2)=10.175, p=0.001\right.$, Cramer's $\left.V=0.062\right)$, as reported by participants. A greater proportion of men (564 of 971 , or $58.08 \%$ ) declared practicing a PA regularly in leisure time than women (856 of 1657 , or $51.66 \%$ ).

To analyze if there were relations between Sex and Type of PA, a Chi-Square test was conducted. The test showed significant associations $\left(\mathrm{x}^{2}(3,4)=71.252\right.$, $\mathrm{p}<0.001$, Cramer's $V=0.224$ ). Table 4 shows there was a greater proportion of men among the physically active Sportists (mainly Individual, 50.7\%), while a greater proportion of women reported a Body/Movement Practice $(87.0 \%)$ as their main type of PA. 
Table 4. Cross tabs between type of physical activity and participant's sex

\begin{tabular}{|c|c|c|c|c|c|c|}
\hline & & \multicolumn{4}{|c|}{ Type of physical activity } & \multirow[t]{2}{*}{ Total } \\
\hline & & Individual Sport & Collective Sport & Exercise & Body/Move-ment Practice & \\
\hline \multirow{4}{*}{ Participant's sex } & \multirow{2}{*}{ Male } & 141 & 107 & 291 & 24 & 563 \\
\hline & & $(50.72 \%)$ & $(44.40 \%)$ & $(40.76 \%)$ & $(13.04 \%)$ & $(39.73 \%)$ \\
\hline & \multirow{2}{*}{ Female } & 137 & 134 & 423 & 160 & 854 \\
\hline & & $(49.28 \%)$ & $(55.60 \%)$ & $(59.24 \%)$ & $(86.96 \%)$ & $(60.27 \%)$ \\
\hline \multirow{2}{*}{ Total } & & 278 & 241 & 714 & 184 & 1417 \\
\hline & & $(100.00 \%)$ & $(100.00 \%)$ & $(100.00 \%)$ & $(100.00 \%)$ & $(100.00 \%)$ \\
\hline
\end{tabular}

We also looked if participants were differentially distributed according to age categories (18-30 and over 30 years) in different types of PA. A Chi-Square test showed significant associations $\left(\mathrm{x}^{2}(3,4)=33.518, \mathrm{p}<0.001\right.$, Cramer's $\mathrm{V}=0.153)$. In comparison to other types of PA, a smaller proportion of people over 30 years (7\%) was involved primarily in Collective Sport, while in other types of PA, people over 30 years ranged from $22.8 \%$ to $25.3 \%$

\section{Discussion and conclusions}

This study investigated influences of type of physical activity (Collective and Individual Sports, Exercises, and Body/Movement Practices), sex and age on motivations for physical activities (PA). Similar to previous reports (Frederick \& Ryan, 1993; Kilpatrick et al., 2005; Ryan et al., 1997), Interest/Enjoyment, Competence (intrinsic motivations), and Social motives were higher for Sports, in particular Collective in comparison to Exercises. Exercisers, on the contrary, were more motivated by Appearance and Fitness/Health (extrinsic motivations). Body/Movement Practices, in turn, although being composed of several activities frequently defined as Exercises by previous studies, showed a motivational pattern closer to Sports (especially Individual, as both did not differ in any motive). Particularly in Appearance and Fitness/Health motivations, where Exercises have the highest scores, Body/Movement Practices do not differ from both types of Sports. In all other subscales, Body/Movement Practices differed from Exercises.

To our knowledge, this study is the first to show a distinct motivational pattern among different types of PA, when considering Body/Movement Practices as a distinct category, besides Sports and Exercises. Body/Movement Practice can be defined as a kind of activity based on gestuality, expression and care, in which the practice serves the purpose of self-care and provision of care for others (Alves \& Carvalho, 2010; Carvalho, 2006). Our results seem to support such definition. Interestingly, although Sports were more prevalent among men and Body/Movement Practices among women, both showed higher intrinsic motivations than Exercises, practiced similarly by both sexes.

Our categorization included PA as Body/Movement Practices similarly to other studies. For example: Pilates, Yoga, Tai Chi (Vergeer et al., 2017, 2018) and Dance (Vergeer, 2018).

Despite our results, further research is still needed to confirm whether there is sufficient support for considering Body/Movement Practice as a consistent category of PA. For example, there are overlaps between the categories, because some activities can transit between two or more or just have an intermediate pattern (see Figure 1). For example, a sport practiced more for social than competitive motives meets the Body/Movement Practice definition and can be placed at intersection between Sports and Body/Movement Practices. Similarly, Pilates was classified as a Body/Movement Practice but because of its structured series of repetitive exercises, it falls in the intersection between Body/Movement Practice and Exercise. Weightlifting, for example, consists of exercises; however it is performed under competitive, that is, sportive settings, thus fitting the intersection between Sport and Exercise. Also, swimming can be practiced as a weight loss exercise, an Individual Sport or even a Body/Movement Practice, depending upon the personal reasons involved. Thus, even an activity with attributes of all three PA can exist, according to the context.

Regarding sex, we found a difference in motivations for PA: women reported higher Interest/Enjoyment motives than men. Previous studies reported higher Appearance motivation among women (Apostolou \& Lambrianou, 2017; Frederick \& Ryan, 1993; Molanorouzi et al., 2015; Ryan et al., 1997). This result can be culturally specific, as previous studies on Brazilian population also did not find sex difference in Appearance motivation (Andrade Bastos et al., 2006; Gonçalves \& Alchieri, 2010). The result in our sample could have been caused by a higher appearance preoccupation in Brazilian men (mean $=4.73)$, in comparison to other countries (e.g., mean $=4.44$ among Spanish men) (Murcia et al., 2007). Similarly, higher Social motivation was expected among men (Apostolou \& Lambrianou, 2017; Deaner, Balish, \& Lombardo, 2016), which was also found among Brazilian 
men (Andrade Bastos et al., 2006). Although we did not encounter any sex difference, social motivations were more important for Sports (in particularly collective), which was more prevalent among men.

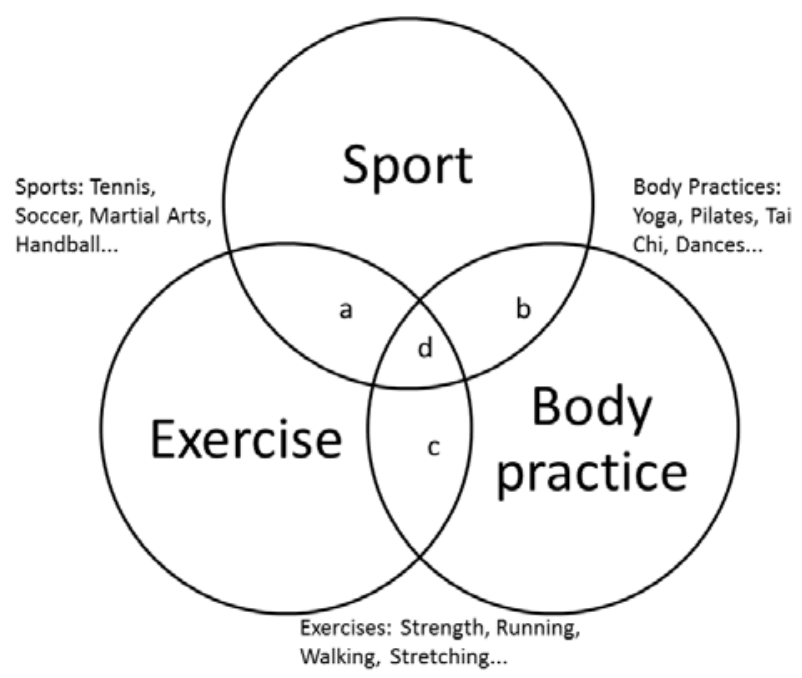

Figure 1. Categories of physical activities (Sport, Exercise, Body/ Movement Practice) considered in this study. $a b c d=$ intersections between the categories suggesting possible overlaps.

The low sex differences in our sample can also be explained by most university participants, where gender inequality is lower than in general society, although still prevalent (Valentova, Otta, Silva, \& McElligott, 2017).

We also asked participants to rate items based on their primary PA (the most practiced), similarly to Frederick and Ryan (1993), whereas most previous studies asked about preferred PA or did not specify. This can generate different results among studies. For example, one can prefer some kind of PA (e.g., golf) but does not have sufficient income to do it frequently, so in the end he/she does most frequently some other activity that may not be as liked as the preferred one. Future studies should explore this issue more, by asking participants to respond about both the most liked PA and the most practiced one.

In line with previous studies, a greater proportion of men reported doing some type of PA regularly. In particular, the relative proportion of men in sports, mainly Individual, surpassed that of women, which can be analyzed through an evolutionary lens. In hunter-gatherer societies, consistently more men engage in hunt and war (Apostolou \& Shialos, 2018), activities closely similar to Sports, while women are more engaged in gathering foods, which is more similar to Body/Movement Practices, defined by a great care/nurture (Carvalho, 2006). Even in contemporary societies, men are more engaged and enjoy hunting and women enjoy more gathering (Apostolou \& Shialos, 2018). Considering, for example, the necessity to run in extreme situations for both sexes, it is reasonable to expect equilibrium in the prevalence of Exercises. Our results are also very similar to Ferrari, Silva, Melo and
Cardoso's (in press) construct of motor orientation, which proposes a greater combativeness orientation in men, while a greater rhythmicity for women. Combativeness is very present in many sports, which were more practiced by men, while rhythmicity is present in several artistic Body/Movement Practices, such as dances, mainly practiced by women.

Finally, comparing the motives, the low Social motivation (with an exception to Collective Sports) is particularly interesting. This finding is similar to previous studies (Alltonen et al., 2014; Apostolou \& Lambrianou, 2017; Ryan et al., 1997) and suggests that, in general, people may value more other ways to socialize than through PA. On the other hand, Fitness/Health seems to be the most inspiring reason for practicing PA, which can make people reflect on the health benefits that PA offer and start doing it. This is in line with the positive correlation between age and Fitness/Health motivation, as chronic diseases commonly manifest more with increasing age (Kennedy et al., 2014), and PA is a strong protection factor (Durstine et al., 2014).

Although the categorization into Sports, Exercises, and Body/Movement Practices was an attempt toward a better comprehension of PA participation, this may have resulted in simplification and loss of differences within the categories. For example, Andrade Bastos et al. (2006) found differences in motivations comparing participants in fitness programs and walkers, who, in our study, were analyzed together as Exercise participants. Future studies could address this issue more thoroughly and see which specific activities are more similar in motivations despite the broader category. Another possibility is to test motives using other criteria for classification of PA, such as motor/ sportive orientation (Ferrari, Silva, Melo, \& Cardoso, in press; Gill \& Deeter, 1988), or even more perceptual and motor criteria, such as task complexity (Naylor \& Briggs, 1963).

Our classification can have practical implications since the motivational profile could be compared with each person's preferences and past experiences with PA to give advice toward the practice of other types of PA. Another possibility is to emphasize more intrinsic motives during interventions. Although extrinsic motives are not necessarily negative, since they vary in degree of autonomy (Batia, 2007; Ryan \& Deci, 2000), and they are also good reasons for initiation in PA, intrinsic motivations reflect more autonomous, self-determined behaviors and are more related to adherence, deliberate practice and engagement and also positive responses (Batia, 2007; Ryan et al., 1997; Vink \& Raudsepp, 2018; Vink, Raudsepp, \& Kais, 2015).

Future studies might also include personality into the model of motivations for different types of PA. This could help clarify the phenomenon, partially because PA can have a strong self-presentational component (Howle et al., 2015), similar to social networking sites, and research shows several interesting relationships among 
social networking sites and personality ${ }^{3}$. Also, it would be of interest to test if time of practice has an effect on motivation, i.e. if a group that practices for more time has more intrinsic motivations compared with one that practices less. Recent research suggests this possibility (Larson, McFadden, McHugh, Berry, \& Rodgers, 2018). Such variables could also be compared considering education (e.g., undergraduates vs graduates), since there is evidence for difference in intrinsic motives according to level of education (Sevil, Sánchez-Miguel, Pulido, \& Pizarro, 2018). Future studies may also integrate motivational analyses with perceived health barriers to PA practice (Warner, Wolff, \& Spuling, 2017).

This is the first empirical test of a categorization of PA into Sports, Exercises and Body/Movement Practices. Our findings regarding distinct patterns of intrinsic and extrinsic motivations for the three categories suggest their relative independence. As shown by Carvalho and Manoel (2015), Body/Movement Practices have been almost exclusively studied through the lens of social sciences, such as Collective Health. Thus, this study also contributed to fill this gap, by adding a psychological approach, and also by testing potential differences in motivations with a classification of PA that included Body/Movement Practices as a distinct category from Sports and Exercises.

Finally, we suggest the need of a more operational definition for Body/Movement Practices to avoid confusions. Future studies may address this by focusing more on comparing different methods of classification, considering aspects, such as relative intensity - as proposed by the Compendium of Physical Activities (Ainsworth et al., 2011) -, motor orientation (Ferrari et al., in press), or a data driven classification, by grouping PA according to statistical criteria.

In summary, we tested a classification of physical activities divided into Individual Sports, Collective Sports, Exercises, and Body/Movement Practices. Our results showed different patterns of motivational profiles according to each type of physical activity. Therefore, this classification should be considered in future psychological research of physical activities.

\section{Conflict of interests}

The Authors declare no conflict of interest.

\section{Acknowledgements}

We would like to thank Jerry Hogan for the English proofreading, Irene Delval for the abstract translation to Spanish and Nicolas Gérard Châline for the abstract translation to French. We would also like to acknowledge Cristina Landgraf Lee, Renata Pereira de Felipe, Fernando Luiz Cardoso, Patrícia Izar, Anthonieta Looman Mafra and Michele Schultz for comments and suggestions on earlier versions of the manuscript, and also for the members of EBSEX Lab for all support. We would also like to thank the editors and anonymous reviewers.

\section{Motivação para prática de diferentes atividades físicas: uma comparação entre esportes, exercícios e práticas corporais}

Resumo: Apesar de amplamente conhecidos os benefícios à saúde relacionados à prática de atividade física (AF), o baixo nível de participação segue sendo um problema de saúde pública. Pesquisas anteriores mostraram diferenças motivacionais consistentes entre Esportes e Exercícios. Entretanto, poucos estudos focaram em categorizações mais amplas. Nesta pesquisa, investigamos motivações para prática de quatro categorias de AFs (Esportes Individuais, Esportes Coletivos, Exercícios e Práticas Corporais), assim como possíveis efeitos do sexo e idade em 1.420 indivíduos fisicamente ativos, os quais responderam à Medida de Motivação para Atividade Física Revisada (Motivation for Physical Activity Measure Revised). As motivações intrínsecas foram maiores para os Esportes, enquanto as extrínsecas para os Exercícios. A categoria de Práticas Corporais, embora composta por várias atividades definidas como Exercícios por estudos anteriores, mostrou um padrão motivacional mais próximo dos Esportes. A motivação de Condicionamento/ Saúde aumentou com a idade, enquanto a de Aparência seguiu o padrão inverso. Com relação ao sexo, as mulheres reportaram maior Interesse/Prazer que os homens. Nossos resultados podem ter implicações para a promoção de atividades físicas, sobretudo ao se considerar categorias mais abrangentes que Esportes/Exercícios e sua associação às diferentes motivações para prática.

Palavras-chave: motivações, esporte, exercício, prática corporal.

\section{Motivation pour les activités physiques : une comparaison entre les différents sports, exercices et pratiques corporelles}

Résumé : Malgré les bénéfices bien connus des activités sportives $(\mathrm{PA})$, leur faibles niveau de pratique reste un problème de santé publique. Les motifs de la pratique des Pas sont différents pour les sports et les exercices. Cependant, peu d'études

3 For example, for Facebook, Marshall, Lefringhausen \& Ferenczi (2015);

and for Tinder, Timmermans \& Caluwé (2017). 
ont abordé les motifs de la pratique des PAs en utilisant des catégories plus nombreuses. Dans cet article, nous étudions les motivations pour quatre catégories de PAs (sport individuel, sport collectif, exercices, et pratiques corporelles), et les effets possibles du sexe et de l'âge parmi 1420 individus actifs physiquement. Les participants ont répondu au questionnaire de mesure révisée de la motivation pour les activités physique (MPAMR). Les motivations intrinsèques furent supérieures pour les sports, alors que les praticants des exercices physiques furent plus motivés extrinsèquement. Les pratiques corporelles, bien que composées de plusieurs activités définies dans d'autres études comme exercices, ont montrés un patron de motivations plus proches des sports. Les motivations lié à la santé/forme physique augmentent avec l'âge, alors que les motivations liée à l'apparence diminuent. En ce qui concerne le sexe, les femmes rapportent un intérêt/attrait plus fort que les hommes. Nos résultats sont importants pour la promotion des activités sportives, en particulier quand il s'agit de considérer des catégories autres que les sports et les exercices dans le contexte de l'étude des différentes motivations.

Mots-clés : motivation, sport, exercice, pratiques corporelles.

\section{Motivaciones para la práctica de diferentes actividades físicas: una comparación entre deportes, ejercicios y prácticas corporales}

Resumen: Los bajos niveles de actividad física (AF) continúan siendo un asunto de salud pública, a pesar de ser bien conocidos sus beneficios para la salud. La investigación sobre los motivos para participar en distintas AFs muestra diferencias en la motivación hacia los deportes y ejercicios. Sin embargo, pocos estudios han abordado los motivos para practicar AFs usando más categorías de AF. En este estudio investigamos las motivaciones hacia cuatro categorías de AFs (Deportes Individuales, Deportes Colectivos, Ejercicios y Prácticas Corporales) y los posibles efectos de la edad y el sexo, en una muestra de 1420 individuos físicamente activos. Los participantes respondieron la Medida de la Motivación para la Actividad Física- Revisada (Motivation for Physical Activity Measure Revised). La motivación intrínseca fue más alta para los Deportes mientras que la motivación extrínseca primó en el Ejercicio. La Prácticas Corporales, a pesar de estar compuestas por actividades previamente definidas como Ejercicios, mostraron un patrón motivacional más cercano a los Deportes. La motivación Aptitud/Salud aumentó con la edad, mientras que la motivación por la Apariencia disminuyó. En cuanto al sexo, las mujeres relataron mayor Interés/ Diversión que los hombres. Nuestr Motivaciones, Deporte, Ejercicio, Práctica Corporal os resultados pueden tener implicaciones en la promoción de las actividades físicas, especialmente al considerar otras categorías además de Deportes/Ejercicios en el contexto de las diferencias de motivación.

Palabras clave: motivaciones, deporte, ejercicio, práctica corporal.

\section{References}

Aaltonen, S., Kujala, U. M., \& Kaprio, J. (2014). Factors behind leisure-time physical activity behavior based on finnish twin studies: the role of genetic and environmental influences and the role of motives. BioMed Research International, 931820, 1-8.

Ainsworth, B. E., Haskell, W. L., Herrmann, S. D., Meckers, N., Bassett, D. R. Jr., Tudor-Locke, C., . . . Leon, A. S. (2011). 2011 Compendium of Physical Activities: a second update of codes and MET values. Medicine \& Science in Sports \& Exercise, 43(8), 1575-1581.

Alves, F., \& Carvalho, Y. (2010). Práticas corporais e grande saúde: um encontro possível. Movimento, 16(4), 229-244.

Andrade Bastos, A., Salguero, A., \& González-Boto, R. (2006). Motives for participation in physical activity by Brazilian adults. Perceptual and Motor Skills, 102(2), 358-367.

Apostolou, M., \& Lambrianou, R. (2017). What motivates people to do and watch sports? Exploring the effect of sex, age, partner status, and parenthood. Evolutionary Psychological Science, 3(1), 20-33.
Apostolou, M., \& Shialos, M. (2018). Why men hunt and women gather for recreation? An Evolutionary Perspective. Evolutionary Psychological Science, 1-9.

Batia, A. (2007). Relationships among personality, selfdetermination and exercise behavior (Doctoral dissertation). University of Florida, Gainesville, USA.

Brasileiro, L. T. (2009). Dança: educação física: (in)tensas relações (Doctoral dissertation). Universidade Estadual de Campinas, Campinas, SP.

Carvalho, Y. M. (2006). Promoção da saúde, práticas corporais e atenção básica. Revista Brasileira Saúde da Família, 7(11), 33-45.

Carvalho, Y. M., \& Manoel E. J. (2015). A survey of body practices and primary health care in a district of São Paulo, Brazil. Motriz: Revista de Educação Física, 21(1), 75-83.

Caspersen, C. J., Powell, K. E., \& Christenson, G. M. (1985). Physical activity, exercise, and physical fitness: definitions and distinctions for health-related research. Public Health Reports, 100(2), 126-131. 
Deaner, R. O., Balish, S. M., Lombardo, M. P. (2016). Sex differences in sports interest and motivation: an evolutionary perspective. Evolutionary Behavioral Sciences, 10(2), 73-97.

Durstine J. L., Gordon B., Wang Z., \& Luo X. (2013). Chronic disease and the link to physical activity. Journal of Sport Health Sciences, 2(1), 3-11.

Ferrari, E. P., Silva, W. R., Melo, G. F., \& Cardoso, F. L. (in press). A vivência de práticas físicas/motoras/esportivas de homens e mulheres para propor o Construto Orientação Esportiva. Revista Brasileira de Educação Física e Esporte.

Florindo, A. A., Guimarães, V. V., Cesar, C. L. G., Barros, M. B. A., Alves, M. C. G. P., \& Goldbaum, M. (2009). Epidemiology of leisure, transportation, occupational, and household physical activity: prevalence and associated factors. Journal of Physical Activity and Health, 6(5), 625-632.

Frederick, C., \& Ryan, R. M. (1993). Differences in motivation for sport and exercise and their relations with participation and mental health. Journal of Sport Behavior, 16(3), 124-146.

Gill, D. L., \& Deeter, T. E. (1988). Development of the sport orientation questionnaire. Research Quarterly for Exercise and Sport, 59(3), 191-202.

Gillet, N., \& Rosnet E. (2008). Basic need satisfaction and motivation in sport. The Online Journal of Sport Psychology, 10(3), 141187443.

Gnerre, M. L. A. (2010). Identidades e paradoxos do yoga no Brasil: caminho espiritual, prática de relaxamento ou atividade física? Fronteiras, 12(21), 247-270.

Gonçalves, M. P., \& Alchieri, J. C. (2010). Motivação à prática de atividades físicas: um estudo com praticantes não-atletas. Psico-USF, 15(1): 125-134.

Hoffman, S. J., \& Harris, J. C. (2013). Introduction to Kinesiology. In S. J. Hoffman, Introduction to kinesiology: studying physical activity (4th ed., not paged). Champaign: Human Kinetics.

Howle, T. C., Jackson, B., Conroy, D. E., \& Dimmock, J. A. (2015). Winning friends and influencing people: Self-presentation motives in physical activity settings. International Review of Sport and Exercise Psychology, 8(1), 44-70.

Kennedy, B. K., Berger, S. L., Brunet, A., Campisi, J., Cuervo, A. M., Epel, E. S., . . . Sierra, F. (2014). Geroscience: linking aging to chronic disease. Cell, 159(4), 709-713.

Kilpatrick, M., Hebert, E., \& Bartholomew, J. (2005). College students' motivation for physical activity: differentiating men's and women's motives for sport participation and exercise. Journal of American College Health, 54(2), 87-94.

Larson, H. K., McFadden, K, McHugh TLF, Berry, T. R., \& Rodgers, W. M. (2018). When you don't get what you want - and it's really hard: exploring motivational contributions to exercise dropout. Psychology of Sport and Exercise, 37, 59-66.

Lazzarotti Filho, A., Silva, A. M., Antunes, P. D. C., Silva, A. P. S., \& Leite, J. O. (2010). O termo práticas corporais na literatura científica brasileira e sua repercussão no campo da Educação Física. Movimento, 16(1), 11-29.

Marshall, T., Lefringhausen, K., \& Ferenczi, N. (2015). The Big Five, self-esteem, and narcissism as predictors of the topics people write about in Facebook status updates. Personality and Individual Differences, 85, 35-40.

Molanorouzi, K., Khoo, S., \& Morris, T. (2015). Motives for adult participation in physical activity: type of activity, age, and gender. BMC Public Health, 15(1), 1-12.

Murcia, J. A. M., Gimeno, E. C., \& Camacho, A. M. (2007). Validación de la escala de medida de los motivos para la actividad física-revisada en españoles: diferencias por motivos de participación. Anales de Psicología, 23(1), 167-176.

Naylor, J. C., Briggs, G. E. (1963). Effects of task complexity and task organization on the relative efficiency of part and whole training methods. Journal of Experimental Psychology, 65(3), 217.

Nunes, T. D. C. L. (2008). Yoga: do corpo, a consciência; do corpo à consciência. O significado da experiência corporal em praticantes de yoga (Tese de doutorado). Universidade Federal de Santa Catarina, Florianópolis, SC.

Ryan, R. M., \& Deci, E. L. (2000). Self-determination theory and the facilitation of intrinsic motivation, social development, and well-being. American Psychologist, 55(1), 68-78.

Ryan, R. M., Frederick, C., Lepes, D., Rubio, N., Sheldon, K. M. (1997). Intrinsic motivation and exercise adherence. International Journal of Sport Psychology, 28(4), 335-354.

Sevil, J., Sánchez-Miguel, P. A., Pulido, J. J., \& Pizarro, A. P. (2018). Motivation and physical activity: differences between high school and university students in Spain. Perceptual and Motor Skills, 125(5): 894-907.

Timmermans, E., \& De Caluwé, E. (2017). To Tinder or not to Tinder, that's the question: An individual differences perspective to Tinder use and motives. Personality and Individual Differences, 110, 74-79.

Valentova, J. V., Otta, E., Silva, M. L., \& McElligott, A. G. (2017). Underrepresentation of women in the senior levels of Brazilian science. PeerJ, 5, 1-20.

Vergeer, I. (2018). Participation motives for a holistic dancemovement practice. International Journal of Sport and Exercise Psychology, 16(2), 95-111.

Vergeer, I., Bennie, J. A., Charity, M. J., Harvey, J. T., van Uffelen, J. G., Biddle, S. J., . . . Eime, R. M. (2017). Participation trends in holistic movement practices: a 10year comparison of yoga/Pilates and t'ai chi/qigong use among a national sample of 195,926 Australians. BMC Complementary and Alternative Medicine, 17(1), 296. 
Vergeer, I., Bennie, J. A., Charity, M. J., van Uffelen, J. G., Harvey, J. T., Biddle, S. J., . . Eime, R. M. (2018). Participant characteristics of users of holistic movement practices in Australia. Complementary Therapies in Clinical Practice, 31, 181-187.

Vink, K., \& Raudsepp, L. (2018). Perfectionistic strivings, motivation and engagement in sport-specific activities among adolescent team athletes. Perceptual and Motor Skills, 125(3), 596-611.

Vink, K., Raudsepp, L., \& Kais, K. (2015). Intrinsic motivation and individual deliberate practice are reciprocally related: evidence from a longitudinal study of adolescent team sport athletes. Psychology of Sport and Exercise, 16, 1-6.

Warner, L. M., Wolff, J. K., Spuling, S. M., et al. (2017). Perceived somatic and affective barriers for self-efficacy and physical activity. Journal of Health Psychology, 24(13), 1850-1862.

Received: $21 / 11 / 2019$

Reviewed: $11 / 06 / 2020$

Approved: 24/08/2020 